\title{
Present Status of Marine Puffer Fishes in Bangladesh
}

\section{Shamsuzzaman $\mathrm{MM}^{1 *}$, Rashid $\mathrm{AHA}^{2}$, Mamun MAA ${ }^{3}$, Mazumder $\mathrm{SK}^{2}$ and Haque MA}

${ }^{1}$ Department of Coastal and Marine Fisheries, Sylhet Agricultural University, Sylhet-3100, Bangladesh ${ }^{2}$ Department of Aquatic Resource Management, Sylhet Agricultural University, Sylhet-3100, Bangladesh

${ }^{3}$ Department of Fish Health Management, Sylhet Agricultural University, Sylhet-3100, Bangladesh

${ }^{4}$ Bangladesh Fisheries Research Institute, Marine Fisheries and Technology Station, Cox's bazar, Bangladesh

\begin{abstract}
The study was conducted to create a checklist of available species of marine puffer fishes of Bangladesh. Cox's Bazar was selected as the study area as common marine fish landing stations are situated there. The study was conducted for a period of one year form July 2011 to June 2012. Puffers were sampled form the fishing vessels on landing stations after return from the sea and also form the local fish markets in four seasons viz. winter, pre-monsoon, monsoon and post monsoon. Most of the fishes were much abundant in the winter season than that of other seasons. After the completion of the study, a total of nine marine puffer fish species were found asTakifugu poecilonotus, Chelonodon laticeps, Takifugu oblongus, Arothron stellatus, Lagocephalus lunaris, Takifugu vermicularis, Arothron Leopardus, Lagocephalus sceleratus and Arothron immaculatus. The most abundant species was Takifugu vermicularis followed by Lagocephalus lunaris while the lowest abundance was observed for Takifugu poecilonotus.
\end{abstract}

Keywords: Puffer fish; Cox’s bazar; Seasons; Bangladesh

\section{Introduction}

Puffer fishes belong to the family Tetraodontidae [1]. The family includes many familiar species, which are variously called puffer fish, puffers, balloon fish, blowfish, bubble fish, globefish, swellfish, toadfish, toadies, honey toads, sugar toads, sea squab etc. They are called puffer fish because of their ability to inflate themselves with water or air when they feel threatened. They use air to expand its body to look intimidating to predators. Tetradotoxin, the puffer fish's toxin, is usually present in the liver, gall bladder, intestine, gonads (ovaries and testes), eggs, and skin of the fish in sufficient amounts to cause intoxication among people who eat the fish. These toxins are 1,200 times more deadly than the poison cyanide [2] and can affect a person's central nervous system of human [3]. Mild intoxication includes light-headedness, numbness of the lips etc. Tetradotoxin poisoning deadens the tongue and lips, and induces dizziness and vomiting, followed by numbness and prickling over the body, rapid heart rate, decreased blood pressure, and muscle paralysis. The toxin paralyzes diaphragm muscles and eventually stops breathing [4]. They are often cheaper than other fishes, and because they contain inconsistent levels of toxins between seasons, there is little awareness or monitoring on its danger. Actually the puffers do not produce toxins themselves. Tetrodotoxin is assumed to be a metabolic product of the host. This toxin is produced by microorganisms, mainly algae engulfed by the puffer which is a subject related to season and this toxin is then bioaccumulated in their body. This puffer fish poisoning is relatively common in some Asian countries, particularly in Japan, Thailand, China and also in Bangladesh [5]. This toxin is both heat and acid stable [6], so are not destroyed by cooking, freezing or by digestion process. Tetrodotoxin poisoning has no specific antidote, but immediate supportive treatment and judicious administration of neostigmine, along with atropine, can minimize fatalities [7].

In Bangladesh, puffer poisoning attributed to ingestion of puffers as a rising health problem over the last $10-15$ years in the country. These incidences occurred due to ingestion of puffers, mainly the freshwater forms [8]. Perhaps, in many cases in the ancient times puffer intoxication could not be identified due to the lack of research and proper examination. The most frustrating case is even during this age of science, people are dying after eating puffer. In addition, there is no exact information of when and where, for the first time the incident of death occurred in Bangladesh after eating this fish. Between 1994 and 1996, seven poising incidents involving 43 patients with 16 deaths due to consumption of freshwater puffer fish were reported [9]. In 1998, a serious food poisoning incident involving 8 people with 5 deaths occurred in Cox's Bazar due to ingestion of roe of a marine puffer Takifugu oblongus [10] and, the panic has spread all over the country. In 2008, in South Bateshwar village of the Belabo Upzaila, Narshingdi, 95 people who had consumed puffer fish; 79 developed toxicity characterized by tingling sensation in the body, perioral numbness, dizziness, and weakness, 16 of them died. A total of 36 victims, including seven deaths incident resulting from the ingestion of the marine puffer Takifugu oblongus occurred at Degholia in the Khulna district of Bangladesh on 18 May 2002.

In Bangladesh, only 3 species of freshwater puffer fish (Tetradon cutcutia, Chelonodon patoca and Tetradon fluviatilis) are available but we do not have any published research information regarding the species numbers of marine puffer. Marine puffers are mainly distributed in the Bay of Bengal. Coastal fishermen reported that some local businessmen distributed the fresh puffers to non-coastal parts of the country [11], where people were fully unfamiliar with those larger varieties, to make a quick profit. Lack of knowledge about marine puffer toxicity contributed to the outbreaks. Moreover, the researchers found some large dried marine puffer fishes to be sold in the local market of Sylhet, where those are sold by attributing new names as nontoxic marine fishes and no publication is yet observed on this important matter. In this context, the study was undertaken as an emergent issue.

${ }^{*}$ Corresponding author: Shamsuzzaman MM, Department of Coastal and Marine Fisheries, Sylhet Agricultural University, Sylhet-3100, Bangladesh, Tel: +8801816434985; E-mail: sakilimsf@gmail.com

Received June 12, 2015; Accepted June 25, 2015; Published July 25, 2015

Citation: Shamsuzzaman MM, Rashid AHA, Mamun MAA, Mazumder SK, Haque MA (2015) Present Status of Marine Puffer Fishes in Bangladesh. J Aquac Res Development 6: 370. doi:10.4172/2155-9546.1000370

Copyright: (c) 2015 Shamsuzzaman MM, et al. This is an open-access article distributed under the terms of the Creative Commons Attribution License, which permits unrestricted use, distribution, and reproduction in any medium, provided the original author and source are credited. 
The objective of the study was to make a checklist of marine puffer fish available in the country which will be helpful in awareness making among the people regarding the puffer fish and their intoxication.

\section{Materials and Methods}

\section{Study area and period of investigation}

The field investigations were conducted for a period of one year from July 2011 to June 2012. Fish samples were collected from two stations of Cox's Bazar Sadar Upazila, Bangladesh in four different seasons. The fish collection stations were Fishery Ghat Bazar and Nazirar tek Artisanal Fish Landing Center (Figure 1). The seasons were- (1) the dry winter season, from December to February; (2) the transition period, from March to May (pre-monsoon); (3) the rainy season, from June to September (Monsoon); and (4) the second transition period, between October and November (post-monsoon) (Figure 1).

\section{Collection of fish sample}

Puffers were sorted from the catch were directly collected from the fish baskets when the fishing boats came to the landing center and immediately preserved with $10 \%$ formaldehyde solution in plastic jar and brought back to the laboratory of the Fisheries Faculty, Sylhet Agricultural University.

\section{Fish identification}

Collected samples were washed gently with tap water and then the morphometric meristic characters were pointed out. Taxonomic studies were done on the basis of the physical features of the collected specimens. The fishes were identified following the works of Holthuis, George, Hossain, Jhingran, Howladar, Shafi and Quddus, Day, George et al., Huda and Hoque and Fischer and Bianchi [12-23]. To establish the views concerning taxonomy of a species, several specimens of different sizes were examined. Attempts have been made to provide valid scientific name of all the genera and species and were listed in accordance with the rules and principles as set forth in the international code.
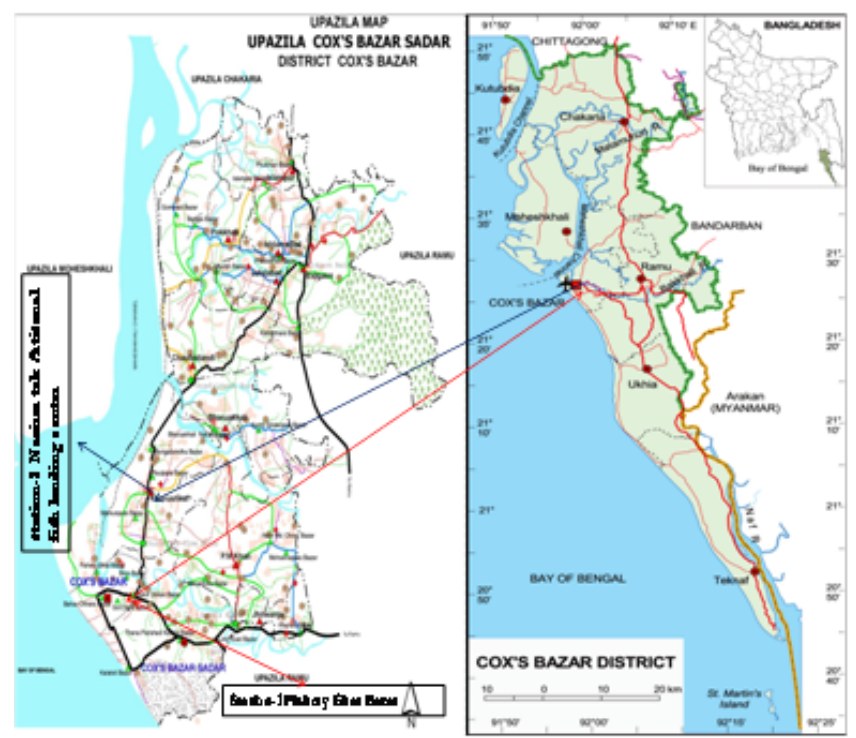

Figure 1: Map of the Study area (Cox's Bazar Upazilla, Fishery Ghat Bazar) (Source: Banglapedia, 2011).

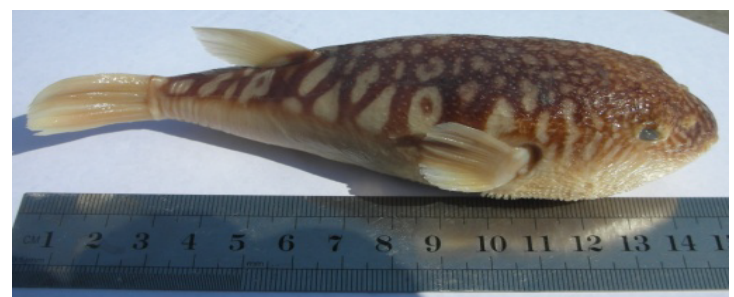

Figure 2: Takifugu poecilonotus.

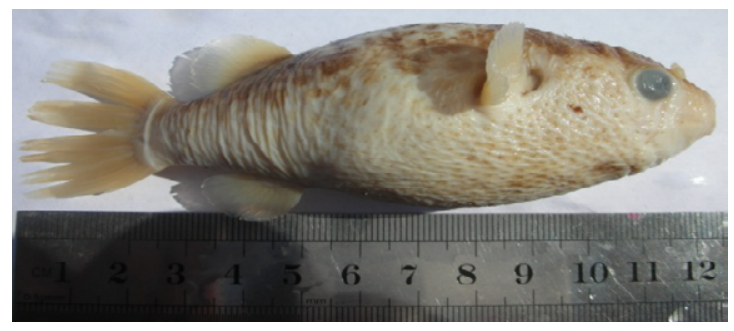

Figure 3: Chelonodon laticeps.

\section{Catch composition analysis}

The weights of each group of species were taken and their percentages of composition were determined. The total numbers of fish in each taxon were also recorded.

\section{Results and Discussion}

This project was undertaken as an emergent issue and research were conducted only for one year. During this period a total of 9 (Nine) species were found from the marine habitat, which are described as follows:

1. Species: Takifugu poecilonotus; Synonyms: Fugu poecilonotus, Fugu poecilonotus, Tetraodon poecilonotus; English names: Fine patterned Puffer, Pufferfish; Local name: Potka; Maximum Size: $20 \mathrm{~cm}$ (TL); Meristic: D. 12-15; A.10-13; P1. 11-14; P. Absent

It's ovary and liver are violently toxic, gonad and skin strongly toxic and flesh is weakly toxic (Figure 2).

2. Species: Chelonodon laticeps; Synonyms: Fugu laticeps, Tetraodon laticeps; English names: Blow Puffer, Pufferfish, swellfish; Local name: Potka; Maximum size: 25 cm (TL); Meristic: D. 11-15; A. 11-15, P1. 10-13; $\mathrm{P}_{2}$. Absent

Toxic part of this puffer is skin and viscera (Figure 3).

3. Species: Takifugu oblongus; Synonyms: Tetrodon oblongus Bloch, 1786, Ausland. Fische, 2: 6; Sphoeroides oblongus Hora, 1924, Mem. Asiat. Soc. Bengal, 6:498; Torguigener oblongus Munro, 1955, Marine and Freshwater Fishes of Ceylon, p. 280; English names: Lattice Blaasop, Oblong Blow Fish; Local name: Dora Potka; Maximum size: $40 \mathrm{~cm}$.

Description: Body fairly elongate. Head broad. Top of head, front part of back and belly with spinules. Eye with a free orbital rim except above. A pair of nasal organ before eye. Upper lateral line running along back anteriorly, gently sloping down to caudal peduncle posteriorly. Lower lateral line, slightly undulating line from chin to caudal base. Head and body covered with long spines. 
Distribution: Indo-West Pacific region from South Africa to Indonesia and Japan including India, Sri Lanka and Bangladesh. Several specimens were collected from St. Martin's Island.

Status and conservation: Not considered as a Threatened fish in the Red List of IUCN (2006).

Remarks: The fish contains poison called tetradotoxin in the internal organs, especially in liver and ovaries. There had been reports of death by eating the fish. Skin, gonad and viscera of this puffer are toxic (Figure 4).

\section{Species: Arothron stellatus;}

Synonyms: Tetrodon lagocephalus stellatus Bloch and Schneider, 1801, Systerna lchthyol., p. 503; Tetrodon stellatus Day, 1878, The Fishes of India, p. 705; Diodon asper Cuvier, 1818, Mern. Mtis. Hist. Nat. Paris, 4: 138; Tetraodon calamara Ruppell, 1829, Fische Rot hen Meeres, p. 64; Kanduka michiei Hora. 1925, Rec. indian Mus., 26: 579; English names: Starry Puffer Fish, Starry Blowfish; Local name: Badami Potka; Maximum size: $120 \mathrm{~cm} \mathrm{[24].}$

Description: Body oblong. Dorsal profile arched, upper profile of snout slightly concave. Interorbital space broad and flat. Eye high, above level of mouth, but not interfering with upper profile of head. Carries 2 nasal tentacles on each side. A suture dividing both the jaws; Jaws modified to form a beak of 4 heavy, powerful teeth, 2 above and 2 below. Back and sides to below level of pectorals covered with brown spots. Pectoral yellowish with brown spots. Meristic: D 10-11; P1 1719; P2 absent; A 10-12. (2000)

Status and conservation: Not in the Red List of IUCN Bangladesh

Distribution: Indo-Pacific region from Red Sea throughout SouthEast Asia to Pacific Ocean including the Bay of Bengal and Bangladesh. Reported from Bangladesh by Shafi and Quddus [19]. Also reported from the Sundarbans area of Bangladesh [22].

Remarks: All species of the group have the ability to inflate their body with air. Considered as the giant among puffers reaching a total length well in excess of a meter. The ovary of this species is violently toxic while the flesh is nontoxic (Figure 5).

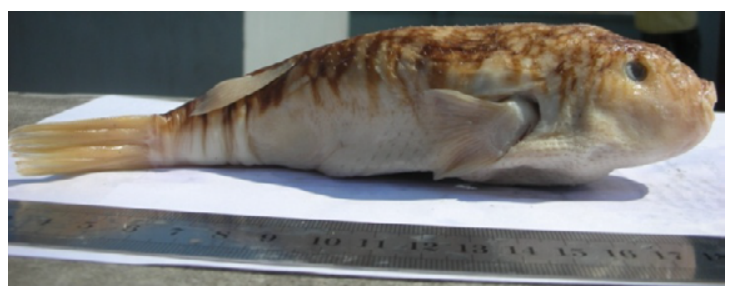

Figure 4: Takifugu oblongus.

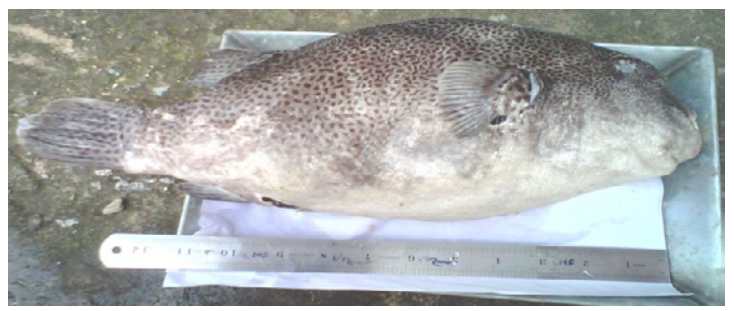

Figure 5: Arothron stellatus

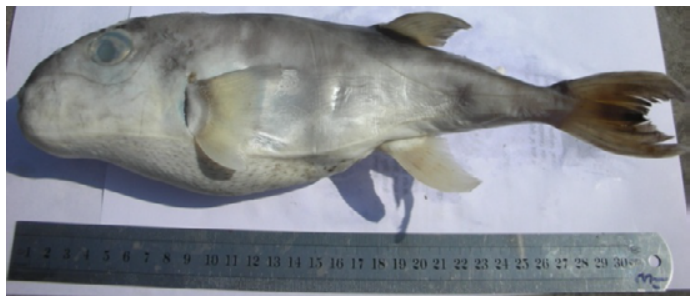

Figure 6: Lagocepha luslunaris.

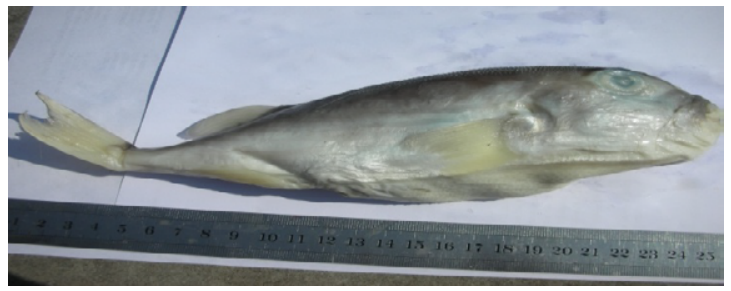

Figure 7: Takifugu vermicularis

\section{Species: Lagocephalus lunaris}

Synonyms: Tetrodon lunaris Bloch and Schneider, 1801, Systema Ichthyol., p. 505; Tetraodon lunaris Bleeker, 1852, Verh. Bat. Gen., 24 12; Spheroides lunaris Jordan and Seale, 1907, Proc. Day. Acad. Sci., 10: 14; Gastrophysus lunaris Munro, 1955, Marine and Freshwater Fishes of Ceylon, p. 280; Sphoeroides lunaris Weber and de Beaufort, 1960, Fishes of the Indo-Australian Archipelago, p. 378. English names: Green Pufferfish, Blowfish, Green Rough-backed Puffer; Local name: Photka

Description: Body elongate with a rounded back. Head broad; bony interorbital space flat. Eyes high, above level mouth. A pair of nostrils before each eye. Two lateral lines, lower line is straight ridge from chin to caudal peduncle. A yellowish line from eye to middle of caudal.

Largest recorded size: $45 \mathrm{~cm}$ standard length. Meristic: D XII-XIV; P1 16-19; P2 absent; A 11-12.

Distribution: Indo-West Pacific region including India, Bangladesh, Thailand, Malaysia, Indonesia, the Philippines, Hong Kong and China. Status and conservation: The status of the species has not been assessed in the Red List of IUCN Bangladesh (2000) (Figure 6).

\section{Species: Takifugu vermicularis}

Synonyms: Fugu vermicularis, Spheroides abbotti, Tetraodon vermicularis:English names: Pear puffer, Purple puffer, Purple Pufferfish; Local Name: Potka; Maximum size: $30 \mathrm{~cm}$ (TL); Meristic: D.12-15; A.10-13; ; $\mathrm{P}_{1}$. 16-19; $\mathrm{P}_{2}$. Absent.

Toxic part of this puffer is skin and viscera (Figure 7).

\section{Species: Arothron Leopardus}

Synonym: Tetrodon leopardus Day, 1878, Fishes of India, p. 706; English name: Banded Leopard Blowfish; Local name: Bagha Potka

Description: Body elongated. Dorsal profile slightly arched. Eyes high, above level of mouth, $1 \frac{112}{2}$ diameter apart. Spines extend from front edge of eyes to dorsal fin. Below they are close together and reach the vent. A single lateral line on side of body. Nasal organ with 2 bifid tentacles. Dorsal situated in the last third of the body. Reticulated narrow black interspaces between large white spots on caudal and dorsal. Meristic: D 11; P1 18; P2absent; A8-9. 
Distribution: Indian Ocean including India, Sri Lanka and Bangladesh.

Status and conservation: The status of the species has not been assessed in the Red List of IUCN Bangladesh (2000).

Remarks: Its overy is violenty toxic, liver and skin also toxic while flesh is nontoxic (Figure 8).

\section{Species: Lagocephalus sceleratus}

Synonyms: Tetraodon sceleratus Gmelin, 1789, Sys. Nat. Linnaeus, p. 1444; Gastrophysus argenteus Bleeker, 1855, Verh. Akad. Amsterdam, 2: 16; Tetrodon sceleratus Day, 1878, Fishes of India, p. 701; Gastrophysus sceleratus Munro, 1955, The Marine and Fresh Water Fishes of Ceylon, p. 280; Spheroides sceleratus Jordon and Snyder, 1901, Proc. U.S. Nat. Mus., 24: 234; English names: Spotted Rough-backed Blowfish, Silver Toadfish; Local name: Photka

Description: Body elongated with a rounded back. Head broad; bony interorbital space flat. Eyes high, above level of mouth. Whole body spinous except the sides. A pair of nostrils before the eye. Sensory canals on head surrounding the eyes. Two lateral lines, lower line running from the chin in a straight line to base of caudal. Dorsal and anal pointed, somewhat falcate. Pectorals pointed. Caudal forked. Olive green above with numerous brown or black spots. Whitish laterally and below with a silvery longitudinal band. A triangular white spot in front of the eye. Fins pinkish. Largest recorded size is $110 \mathrm{~cm}$ in standard length. Meristic: D. 10-12; A. 9-11; $\mathrm{P}_{1}$. 16-17, $\mathrm{P}_{2}$. Absent

Distribution: Indo-West 'Pacific region from Southern Africa to Australia including India, Sri Lanka and Bangladesh.

Remarks: Its liver and ovary are strongly toxic while skin and flesh are weakly toxic. The poisonous organs are removed by specialist cooks on the day fish is caught (Figure 9).

\section{Species: Arothron immaculatus}

Synonyms: Tetrodon immaculatus Bloch and Schneider, 1801, Syst. lchth., p. 507; Tetraodon sordidus Ruppell, 1829, Fische Rothen Meeres, p. 64; Tetraodon aspilos Bleeker, 1851, Nat. Tijds. Ned. Indie, 2: 495; Tetrodon irninaculatus Day, 1878, Fishes of India, p. 703; Tetraodon

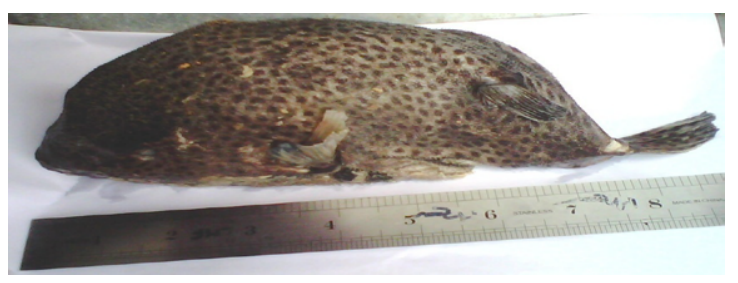

Figure 8: Arothron leopardus.

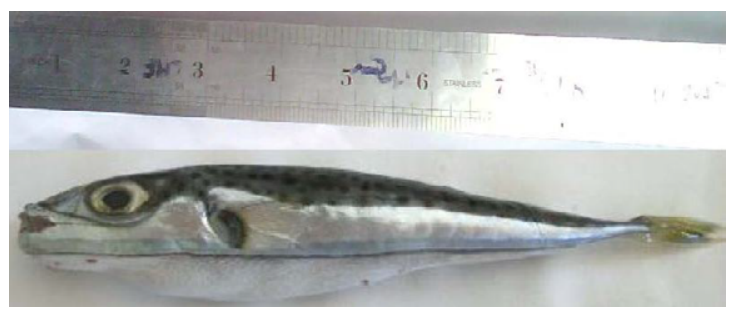

Figure 9: Lagocephalus sceleratus.

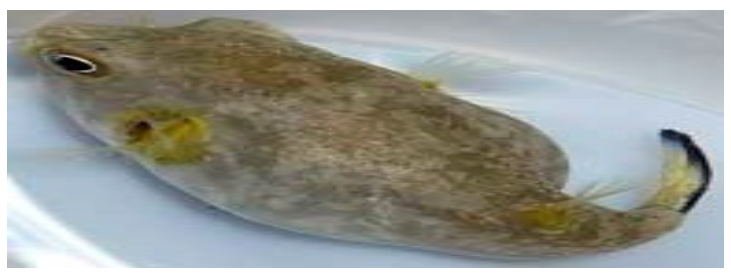

Figure 10: Arothron immaculatus.

\begin{tabular}{|l|c|}
\hline Fish Species & Percentage (\%) by presence (number) \\
\hline Takifugu poecilonotus & 6.0 \\
\hline Chelonodon laticeps & 8.2 \\
\hline Takifugu oblongus & 9.7 \\
\hline Arothron stellatus & 11.5 \\
\hline Lagocephalus lunaris & 13.1 \\
\hline Takifugu vermicularis & 20.2 \\
\hline Arothron Leopardus & 9.2 \\
\hline Lagocephalus sceleratus & 11.8 \\
\hline Arothron immaculatus & 10.3 \\
\hline Total & 100 \\
\hline
\end{tabular}

Table 1: Frequency of fish species presence in the research areas.

\begin{tabular}{|l|c|c|c|c|}
\hline Scientific name & \multicolumn{4}{|c|}{ Seasons } \\
\cline { 2 - 5 } & $\begin{array}{c}\text { Winter Season } \\
\text { (December to } \\
\text { February) }\end{array}$ & $\begin{array}{c}\text { Pre-monsoon } \\
\text { period } \\
\text { (March to } \\
\text { May) }\end{array}$ & $\begin{array}{c}\text { Rainy season } \\
\text { (June to } \\
\text { September) }\end{array}$ & $\begin{array}{c}\text { Post- } \\
\text { monsoon } \\
\text { (October to } \\
\text { November) }\end{array}$ \\
\hline Takifugu poecilonotus & ++ & - & + & + \\
\hline Chelonodon laticeps & ++ & + & - & ++ \\
\hline Takifugu oblongus & ++ & ++ & + & + \\
\hline Arothron stellatus & ++ & + & + & + \\
\hline Lagocephalus lunaris & ++ & ++ & + & - \\
\hline Takifugu vermicularis & ++ & + & - & + \\
\hline Arothron Leopardus & + & + & - & ++ \\
\hline Lagocephalus sceleratus & ++ & - & + & + \\
\hline Arothron immaculatus & + & - & - & + \\
\hline
\end{tabular}

++=More present, +=Less present, -=Absent

Table 2: Seasonal variation of fish species between two study area.

iinrnaculatus Fowler, 1903, Proc. Acad. Nat. Sd. Philadelphia, 55: 165; English names: Immaculate Puffer, Immaculate Blowfish; Local name: Potka; Maximum size: $30 \mathrm{~cm}$ [25].

Distribution: Indo-West Pacific region from Red Sea and East Africa (including the south coast of South Africa) to Indonesia, north to Southern Japan including India, Bangladesh, Sri Lanka, Malaysia, Maldives, the Philippines, Thailand.

Status and conservation: Not in the Red List of IUCN Bangladesh (2000) (Figure 10).

\section{Frequency of fish species presence}

During the study period nine puffer fish species was found in the observed area. Among them the highest presence were observed for Takifugu vermicularis (20.2\%) followed by Lagocephalus lunaris while the lowest were observed for Takifugu poecilonotus (Table 1).

\section{Seasonal variation of fish species}

The species were usually abundant in the winter seasons. On the 
Citation: Shamsuzzaman MM, Rashid AHA, Mamun MAA, Mazumder SK, Haque MA (2015) Present Status of Marine Puffer Fishes in Bangladesh. J Aquac Res Development 6: 370. doi:10.4172/2155-9546.1000370

Page 5 of 5

other hand in the monsoon they were found to be least abundant in the catch (Table 2).

\section{Conclusion}

This study provides information regarding the occurrence of puffer fish in Cox's Bazar Sadar representing Bay of Bengal. There is no published research data on marine puffers availability in Bangladesh. Moreover, catching of fish is largely dependent upon seasons, types of trawl nets used and location of fishing spots. So, from this short period of research, only 9 species were collected and observed. Most marine puffer fishes are not attractive looking and have very lower value as table fish in context of Bangladesh; so most of those are discarded in the sea from catch after sorting on trawl board which hampers its easy collection from landings.

\section{Acknowledgement}

The project was funded by Sylhet Agricultural University Research System (SAURES) under the University Grant Commission (UGC) of Bangladesh. We would also like to acknowledge the use of the universities research grant while preparing this publication.

\section{References}

1. Nelson JS (2006) Fishes of the World (4thedn.) John Wiley and Sons, New York.

2. Kaplan EH (2006) Sensuous seas: Tales of a marine biologist. Princeton University Press, US.

3. Tambyah PA, Hui KP, Gopalakrishnakone P, Chin NK, Chan TB (1994) Centralnervous- system effects of tetrodotoxin poisoning. The Lancet 343:538-539.

4. Cheng KK, Ling YL, Wang JCC (1968) The failure of respiration in death by tetrodotoxin poisoning. Exp Physiol 53: 119-128.

5. Noguchi T, Ebesu JSM (2001) Puffer Poisoning: Epidemiology and Treatment Toxin Reviews 20: 1-10.

6. Kuromi H, Gonoi T, Hasegawa S (1979) Partial purification and characterization of neurotrophic substance affecting tetrodotoxin sensitivity of organ-cultured mouse muscle. Brain Research 175: 109-118.

7. Xu QH, Wei CH, Huang K, Rong KT (2005) Toxin-neutralizing effect and activity-quality relationship for mice tetrodotoxin-specific polyclonal antibodies. Toxicology 206: 439-448.
8. Ahmed S (2006) Puffer fish tragedy in Bangladesh: an incident of takifugu oblongus poisoning in Degholia, Khulna. African J Marine Sci 28: 457-458.

9. Zaman $L$ (1997) Studies on neurotoxins in several aquatic organisms

10. Mahmud Y, Tanu MB, Noguchi T (1999) First occurrence of a food poisoning incident due to ingestion of takifugu oblongus, along with a toxicological report on three marine puffer species in Bangladesh. J Food Hyg Soc Japan 40: 473-480.

11. Homaira N, Rahman M, Luby SP, Rahman M, Haider MS, et al. (2010) Multiple outbreaks of puffer fish intoxication in bangladesh, 2008. Am J Trop Med Hyg 83: $440-444$

12. Holthuis LB (1950) The Decapoda of the Siboga Expedition. Siboga Expeditie Mon, Leiden.

13. Holthuis LB (1980) Shrimps and prawns of the world: an annotated catalogue of species of interest to fisheries. FAO Fisheries Synopsis 1: 1-261.

14. George, M.J. 1969 Prawn fisheries of India-2. Systematics taxonomic consideration and general distribution. Bull cent Mr Fish Res INST: 5-48.

15. Hossain KN (1971) The commercial fishes of the Bay of Bengal survey for the development of fisheries, East Pakistan, Chittagong.

16. Jhingran VG (1974) Fish and fisheries of India. Hindustan publishing corporation, New Delhi, India.

17. Howlader JC (1976) A taxonomic account of penaeid shrimps of Bangladesh waters, Bangladesh. J Sci and Ind Res XI (1-4): 122-138.

18. Shafi M, Quddus MMA (1982) Bangladesher Matshya Sampad (in Bangla) Bangla Academy, Dhaka.

19. Shafi S, Quddus KM (1983) Bangopasagarer Matsya Sampad (The fish resources of the Bay of Bengal). Bangla Academy, Dhaka.

20. Day $F$ (1889) The fauna of british india, including ceylon and burma. Annals and Magazine of Natural History: Series 65: 115-117.

21. George HP, Barry DB, Russell C, Bogusch A (1994) The marine fishery resources of sri lanka. FAO, Rome, Italy.

22. Huda MS, Hoque ME (2003) Field guide of finfishes of sundarban. Aquatic resources division, Sundarban, Sundarban biodiversity conservation project Bangleadesh forest department, Boyra, Khulana.

23. Fischer W, Bianchi G (1984) FAO species identification sheets for fishery purposes western indian ocean (fishing area 51). Food and Agricultural Organization of the United Nations, Rome.

24. Lieske E, Myers R (1994) Collins pocket guide coral reef fishes indo-pacific and caribbean including the red sea. Harper Collins Publishers, New York, USA.

25. Smith MM, Heemstra PC (1986) Smith's Sea Fishes. Mac-millan, Johannesburg 